\title{
PROPAGANDA REARTICULATION OF A CRIME AGAINST CIVILIZATION: THE CONCEPT OF THERESIENSTADT IN THE SERIES HOLOCAUST
}

UDC 341.485(=411.16)(437)"'1939/1945": 316.774

\section{Ivana Milovanović}

University of Arts Belgrade, Theory of Arts and Media, Serbia

\begin{abstract}
The most notorious Nazi extermination camps or death camps were Auschwitz, Belzec, Treblinka, etc. Apart from the death camps, the Nazis established concentration labor camps where they exploited the labor force. By its function, one of the unique concentration camps was Theresienstadt, which became a Nazi concentration camp for Jews in November 1941. In fact, Terezin was advertised as a spa center for wealthy senior citizens who were promised safety and luxury. Media articles on the topic of the Holocaust have become a significant part of the culture of remembrance. The American television miniseries Holocaust is one of the media narratives that deal with crimes against civilization and its premiere was in 1978. The concept of Theresienstadt in the series Holocaust corroborates the statement that this camp was used for the purpose of propaganda rearticulation of a crime against civilization and it reveals the hidden and repressed fear and horror underneath the smiling façade of Theresienstadt. The colorfulness of the exterior in the scenes which show Terezin, and on the other hand a horror interior, as well as everything that was happening behind the scenes expressed in the form of secret images of the artists, clearly emphasize the living conditions in Theresienstadt, as well as its role in Nazi propaganda.
\end{abstract}

Key words: propaganda, Holocaust, Theresienstadt, media articles, culture of remembrance

\section{INTRODUCTION}

Media articles on the topic of the Holocaust have become a significant part of the culture of remembrance. "History, remembrance and the memory of the Holocaust from the end of the last millennium to date have been a current topic and the subject of interdisciplinary research in Europe, North America and Israel, and more recently in our

Received July 3, 2016 / Accepted July 21, 2016

Corresponding author: Ivana Milovanović

University of Arts Belgrade, Kosancicev venac 29, 11000 Belgrade, Serbia

E-mail: ivana.milovanovic989@gmail.com 
country as well" (Daković 2014, 135). Research, among other things, includes the analysis of the representation of the trauma and Holocaust through various textual narratives in film and television formats. According to Nevena Dakovic, the turning point of the representational paradigm of film stories of the Holocaust are the documentary Shoah (1985, Claude Lanzmann) ${ }^{1}$ and the film Schindler's List (1993, Steven Spielberg). "Visual representations of crimes are focused on the ethical principles of representation and narrative strategy with an aim to present trauma on a civilizational, cultural, personal or collective level" (Daković 2014, 149).

The most notorious Nazi extermination camps or death camps were Auschwitz, Belzec, Treblinka, etc. Apart from the death camps, the Nazis established concentration labor camps where they exploited labor force. By its function, one of the unique concentration camps was Theresienstadt, which became a Nazi concentration camp for Jews in November 1941. In fact, Terezin was advertised as a spa center for wealthy senior citizens who were promised safety and luxury. Meritorious German and Austrian Jews, veterans who fought on the German side in the First World War, recognized scientists, distinguished artists, especially painters and musicians were transported to this concentration camp. "As soon as they arrived they were robbed of all their last earthly belongings and got shoved into attics and cellars of Theresienstadt where they died in droves, their last moments filled with pain, indignity and deprivation" (Schiff 2012, 6-7). It became a transit camp for Auschwitz-Birkenau almost immediately.

The American television mini-series Holocaust is one of the media narratives to deal with crimes against civilization and its premiere was in 1978. The series was severely criticized for trivializing the crimes committed by the Nazis against the Jews during World War 2. According to Daković, in fact all film narratives of the Holocaust "are created on the basis of real events, as adaptations of documentaries, biographical or autobiographical books, or on the basis of fiction with skillfully twisted and altered reality, which places them in a wide group of fictionalized reality texts and the ethics of evocation is questioned" (Daković 2014, 162).

In this paper, we will try to determine how the concentration camp Theresienstadt was used in the Nazi propaganda of the rearticulation of crimes, primarily through the analysis of how this concept was represented in the television mini-series Holocaust.

\section{THERESIENSTADT - PROPAGANDA CONCENTRATION CAMP}

The city of Terezin is located sixty kilometers from Prague, and its fortress was built in 1784. Inside the fortress was a garrison for the accommodation of the Habsburg Monarchy army, but it was also the well-known dungeon where Gavrilo Princip served his prison sentence. The Germans chose this fortress built in the eighteenth century by the AustroHungarian Emperor Joseph II as an ideal location for a concentration camp for the transit of Jews. "It was extremely well suited for this sinister purpose. Theresienstadt's location was significant because it is only some $60 \mathrm{~km}$ north of Prague, well on the way to Poland, the site of so many death and concentration camps where many of the inmates were ultimately sent" (Schiff 2012, 3-4).

\footnotetext{
${ }^{1}$ Shoah is a Franco-British documentary film directed by Claude Lanzmann in 1985. The film contains the interviews with witnesses of the Holocaust and the footage made at the site of the genocide.

${ }^{2}$ The film Schindler's List is based on the novel Schindler's Ark by Thomas Keneally. The director of this Oscar-winning film is Steven Spielberg.
} 
Theresienstadt became a Nazi concentration camp for Jews in November 1941. According to George Berkeley in his book Hitler's Gift: The Story of Theresienstadt (1993), Theresienstadt was first mentioned in the German press in the summer of 1942. "Suddenly, and magnanimously, the Fuehrer was presenting an entire city to the Jews. The news accounts identified the city as Theresienstadt and gave its location as northern Czechoslovakia some 39 miles from Prague. Theresienstadt's regular residents were being evacuated but would leave behind their furniture for the city's new, and seemingly fortunate, inhabitants" (Berkley 1993, 8).

From 1941 to 1945, it had undergone a drastic transformation. Barracks were built and equipped with three rows of beds and additional houses were built to fit the projected number of future prisoners. The whole city became a prison for Jews. According to Vera Schiff, Terezinstadt was quite a unique place among the Nazi concentration camps. "Theresienstadt, alias Terezin, also dubbed 'Terezin spa', was a hybrid between a ghetto and a concentration camp and it was a very dark and strange place indeed. While in the planning stages little suggested that Theresienstadt would differ from the run-of-the-mill concentration camps that abounded in the Third Reich. The ruling Nazis adapted Theresienstadt to the needs of the quickly changing war scenario" (Schiff 2012, 6).

During 1942, more than 53,000 prisoners were in the camp. Except for being a collection and transit center for the Jewish population, it was also used for propaganda to conceal the true purpose of the Nazi ghettos and concentration camps. This is corroborated by the fact that the Nazis filmed three propaganda films during the war years, which were supposed to represent the ghetto in Terezin as a cultural and lively city. In fact, a large part of the Nazi propaganda was based on film propaganda, both before the war and during the war. "The Propaganda Ministry reacted by issuing a directive in 1938 that every film company had to issue at least one anti-Semitic film, because Germany was entering the war thus the enemies of the homeland had to be publicly denounced and isolated. After the beginning and the escalation of military activities, film production was significantly reduced as a consequence of the lack of material and personnel; however, even after 1943, more than seventy films per year were being filmed" (Trzun 2009, 134).

One of the propaganda films, whose aim was to assure the public that the attitude of the Nazis towards the Jews was at the very least humane, was Terezin: a documentary film of the Jewish residential area (Theresienstadt. Ein Dokumentarfilm aus dem jüdischen Siedlungsgebiet), which was directed by the Jewish director and actor Kurt Gerron in 1944. The film was better known as The Fuhrer Gives a Village to the Jews, and it was filmed following Goebbels commands. In this film, as said by Brad Prager: "The prisoners are performing for the cameras, trying to show that things are normal or even that they are enjoying themselves. The fact that their performance is predicated on concealing their distress and that the film's scenes were produced under their tormentors' watchful eyes should certainly mitigate or nuance our understanding of their participation. We see Jews taking up recreational games instead of being worked to death, and receiving excellent health care instead of dying in large numbers in an environment in which the majority suffered from hunger, tuberculosis and other illnesses" (Prager 2008, 178). The aim of this film was to show how well the Jews lived under the alleged Nazi protection, that is, as Margry said, to deceive the representatives of neutral countries such as Sweden and Switzerland; however, eventually, the film was probably not screened more than four times - mostly for private audience within or near Theresienstadt (Margry 1992, 154). 
A less known Nazi propaganda film about Theresienstadt was the one from 1942. According to Margry, this film was probably filmed by Himlerr's orders and directed by the Czech Jewish female prisoner Irena Dudanowa. Nazi general Otto was in charge of film production supervision. "There are indications that Otto was a sadist who was particularly interested in exploiting female prisoners and perhaps for this reason he wanted the film made. Only eight minutes of this original document remain, presently archived in Warsaw" (Margry 1999: 310). The film shows a Jewish family that was deported from Prague to Theresienstadt.

"In their films, Jews sit in cafes, dance and play swing music, kids play in the playground - all this ends when the cameras are turned off. Real life in Terezin was not allowed to be shown on film. Jews had to be good actors, or else the almost certain death awaited them in the concentration camp. Jews who refused to participate in this faking of real life in the ghetto, or who did not play their roles convincingly were deported to a concentration camp. If they were not happy enough and that could be seen in the film, they would end up in the concentration camp, where they were killed. Only in the German film captured in Terezin could the Jewish kids play happily and swing on the horses."3

According to Radulić, precisely the fate of those children was the most distressing thing that happened in Terezin. Most of them were executed in gas chambers in Auschwitz. "After the war, numerous children's drawings and written documents were found that reveal the thoughts and feelings of the youngest prisoners in the concentration camp, their memories of the home they had to leave, sorrow for the family members they were separated from and hope that they would meet again. Among the Terezin prisoners there were more than 10,000 of those who were less than 15 years old when brought to the concentration camp. Around 250 children were born in the camp, while only 25 of them survived and left the camp. 7590 children were deported from Terezin to the East, while 242 of them survived the Holocaust“" (Radulić 2009).

A lot of pressure was put on Germany to allow International Red Cross visits to some camps. In June 1944, and then in spring 1945 Theresienstadt was visited by representatives of the Red Cross. However, their arrival was preceded by work on creating a false image of the camp.

"Numbers that marked parts of the camp were taken off the buildings and in their place signs with street names that sounded charming and attractive were put. One building was decorated to look like a bank. In order to complete the illusion, they opened a kindergarten, several shops, and even a café in the town center. They rebuilt the façade on the houses, planted greenery in the park in the middle of the town and built a pavilion where the band played music. Thanks to the perfectly staged deception, the delegates in their reports described Terezin as a regular Jewish town and wrote that its people lived well. The Nazis invited Red Cross delegates to visit the castle accompanied by a guide. They were allowed to speak with the Jews who were supposedly representatives of the town administration.

\footnotetext{
${ }^{3}$ The content of these films was altered by the National Film Archive of the Czech Republic in cooperation with the Jewish Museum in Prague. Propaganda: Pogledajte kako su nacisti lažirali život u jevrejskom getu. Buka, December 05, 2013. Accessed April 09, 2016. http://www.6yka.com/novost/45288/propaganda-pogledajtekako-su-nacisti-lazirali-zivot-u-jevrejskom-getu-foto
} 
However, these people were carefully selected, and they had to answer the questions in the exact way the Nazis told them."

One of the representatives of the Red Cross was the Swiss Maurice Rossel who came together with two Danish delegates. He wrote in his report that Terezin "is a place that lives a completely normal life. The text was illustrated with his own photographs of camp inmates, especially the children, which were supposed to corroborate the happy life the Jews lived in Terezin" (Radulić 2009). Based on the "well-staged play", Red Cross delegates who had repeatedly visited Terezin, described it as a Jewish town where residents "live well". With this deception done in the propaganda camp, the Nazis succeeded in their goal to at least briefly silence the rumors about the genocide that was being carried out against the Jews.

According to Hana Radulić, even at the very end of the war, when it became clear that Germany was facing defeat, the Nazis continued to use Terezin as an exemplary town for Jews. "In his attempt to make an agreement with the West and to ensure a better position for Germany, in February 1945 Himmler gave the order that around a thousand Danish Jews from Terezin be transferred to Switzerland, while many Jewish prisoners were supposed to be deported from other camps to Terezin. However, most of them died immediately upon arrival to Terezin after a torturous, long trip" (Radulić 2009).

\title{
3.THE CONCEPT OF THERESIENSTADT IN THE SERIES HOLOCAUST: "WHO EVER HEARD OF A PRISON WITH AN ART STUDIO?"
}

The TV series Holocaust is an American television mini-series which was first broadcast in 1978 on the NBC television network. The series, which consisted of four episodes each lasting for ninety minutes was directed by Marvin Chomsky. Leading roles were: Fritz Weaver, Rosemary Harris, James Woods, Joseph Bottoms, Blanche Baker, Meryl Streep, Michael Moriarty and David Warner. The series received numerous awards including the Golden Globe for the best actor and actress, several Emmy and Grammy awards and many others.

The makers of the series were criticized for presenting a complex topic through a trivial family story in the style of a soap opera and melodrama. The film Schindler's List was criticized in the same way. When writing about the series Holocaust, Daney says:

\begin{abstract}
"So, only in the form of American documentary drama this history will succeed in avoiding to end up in video clubs and through television it will reach "all mankind", i.e. global TV audience. Simulation - the Holocaust is certainly no longer coping with monstrosity of humanity capable of a crime against itself, but it also deals with those humans who have remained stubbornly incapable of telling the story of particular individuals, stories with the face and name belonging to the destroyed Jews (Daney 1992, according to Daković 2014, 150).”
\end{abstract}

When writing about film texts, particularly European, Daković states that: "The analysis of these texts leads to a kind of a rehabilitation of the rejected story model, whose undoubtedly populist tone provides a new reception, interpretation and social

\footnotetext{
${ }^{4}$ Propaganda: Pogledajte kako su nacisti lažirali život u jevrejskom getu. Buka, December, 05, 2013. Accessed April 09, 2016. http://www.6yka.com/novost/45288/propaganda-pogledajte-kako-su-nacisti-lazirali-zivot-ujevrejskom-getu-foto
} 
repositioning of the Holocaust in memory and remembrance" (Daković 2014, 150). Daković further states that many authors emphasized that trivialization, which is undoubtedly a part of any attempt of a melodramatic topic representation, brings with it betrayal, denial and relativization, and above all a wrong view through the denial of the unique character of the events. As she states furthermore, authors, such as Wiesel and Kertesz and others: "pointed out that the deformation of the historical truth and melodramatic kitsch are a typical representation which is helpless or unwilling to understand the primeval connection between our deformed lifestyle (whether at the level of civilization or the individual level), and the very possibility of the Holocaust. However, nowadays, it is possible to talk about changing effects of simplified (hi)stories, with an analysis that develops through a synchronic and diachronic monitoring of changes of the "eclectic strategy" - otherwise inflationary Holocaust narratives" (Daković 2014, 151).

The series Holocaust shows numerous important events that occurred during World War 2, such as Kristallnacht, the creation of Jewish camps, and then the use of gas chambers. The story follows the lives of two German families, the Jewish Weiss family and the German Dorf family. One by one, the Weiss family members suffer the terrible fate of extinction under the rule of Adolf Hitler. The subplot follows the story of Eric Dorf (Michael Moriarty), a young German lawyer who undergoes a transformation from an "ordinary", peaceful man to a mass murderer and right hand of Reinhard Heydrich.

At the very beginning, the series depicts life in Berlin from 1935, and then quickly moves to 1938 and shows the arming of the German army and strengthening of Hitler's influence. The series shows the life of Jews living in numerous concentration camps such as Buchenwald, Auschwitz, the Warsaw ghetto and Theresienstadt where Karl Weiss (James Woods), a prominent Jewish artist was brought in 1942.

One of the first scenes showing Theresienstadt shows the "idyllic picture" of the camp, with colorful façades and buildings such as cafés and banks (Fig. 1). Such an image, which was intended to serve both as a decoration or a film set to shoot propaganda films, and also served to make a good first impression on foreign delegations who would come at the camp, had an impact on Karl, who observed the scene with mild disbelief. One of the artists, who was already in the camp, immediately invited Karl to join their group and solved his dilemma, outlining what was happening behind the scenes of the colorful exterior: "This camp is nothing more than a scam. In the coffee shop you can buy only hot water, the bank uses a useless currency. This is no different from Buchenwald. Germans want to present it as a respected ghetto."

The artists who created their work in Terezinstadt explained to Karl that everything was really just a scam, well designed for foreign delegations, especially those from neutral countries who come and visit. According to Vera Schiff, such a neat settling of the camp was preceded by a visit of the Red Cross delegation in 1944. "A café and several shops were opened that were only window dressing because we could not buy anything. The newly opened bank was also part of the enhancement; even valueless currency was on display. The Nazis ordered the planting of green areas that remained off limits for the inmates. In the main square a music pavilion was erected, home for the camp orchestra, with benches that looked inviting, suggesting that the place was a veritable resort. In the nearby park a playground was developed that was on par with the best of children's parks" (Schiff 2012, 12-13). 


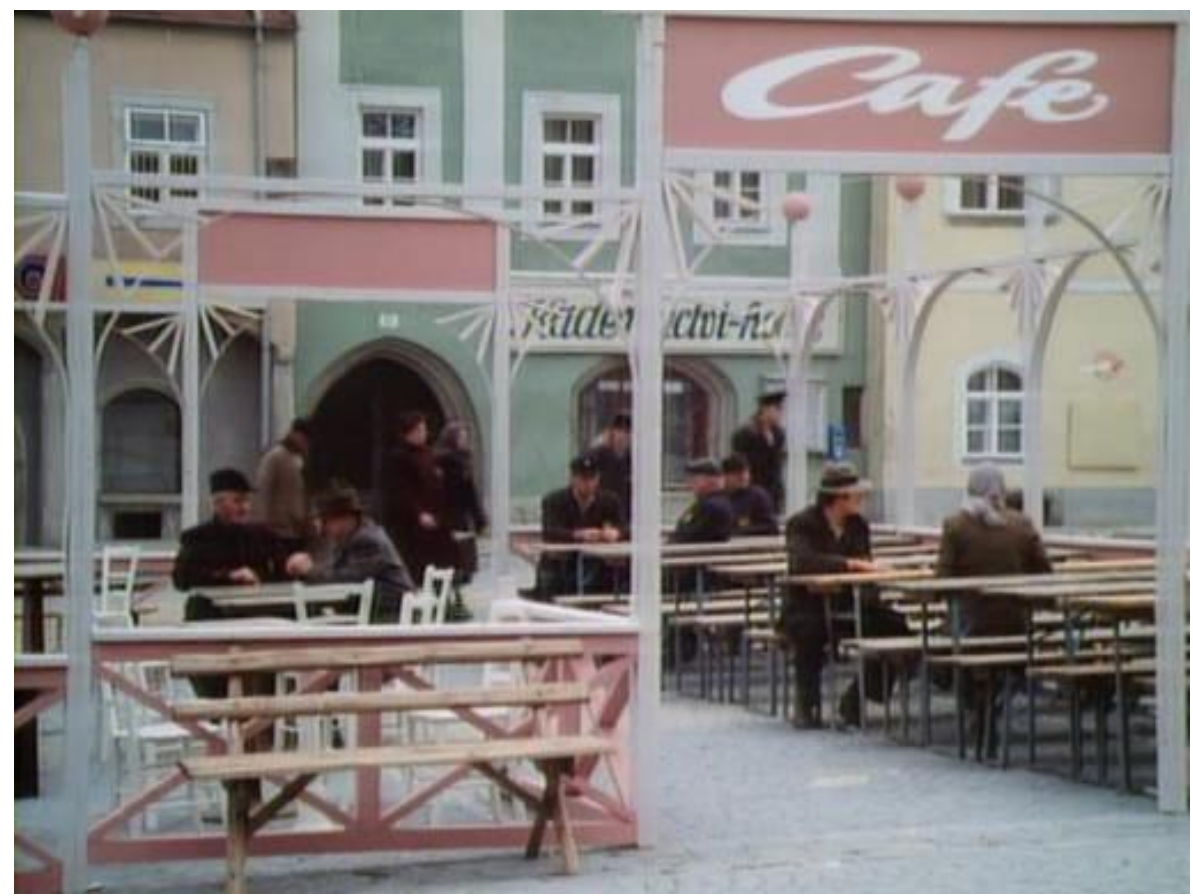

Fig. 1 Square in Theresienstadt

Everyone had to participate in the deceit, including artists, who showed Karl the pictures they painted of children smiling and playing in the camp. These pictures were supposed to serve as a confirmation of the Nazi story of "good living conditions in Terezin". After Karl protested against such scenes, the artists show him works where they presented the real life in the camp. These images were called the "horror-camp" (Figures 2 and 3 ).

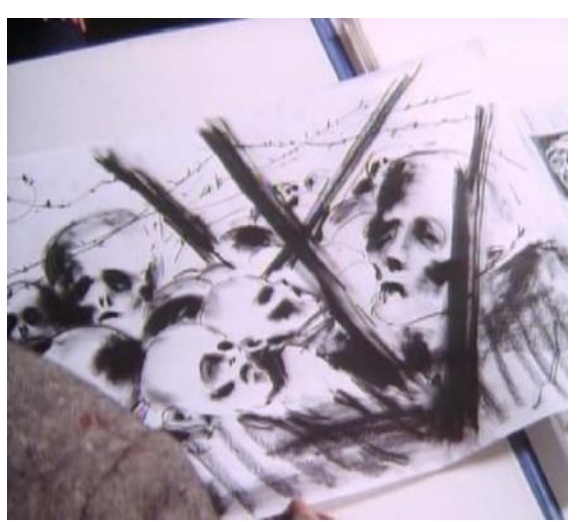

Fig. 2 Real life in Terezin

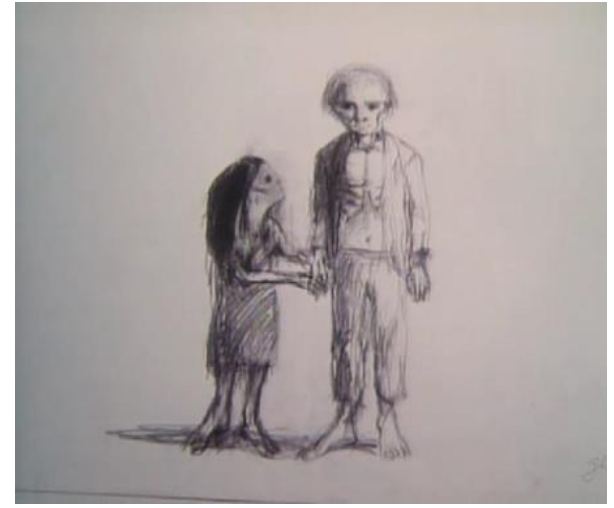

Fig. 3 "Horror-camp" 
It was very important for the Nazis to maintain a false image of Terezin, that is, every part of the story served to confirm their propaganda rearticulation of the crimes, which is why precisely those paintings, which were not in accordance with the false image of life in Terezin, which was supposed to be presented to the rest of the world, were the reason for the torture, murder and transport of "disobedient" artists to Auschwitz. Therefore, the artists were allowed to create, but only the works that would be in line with the image that was allowed to be sent to the world. Among other artists, the Nazis transported Karl to Auschwitz as well, because he did not want to reveal his fellow artists who painted pictures of the horrors of the concentration camps. Shortly before the liberation, Karl died in Auschwitz.

As the war progressed, the news of the genocide that was carried out against the Jews in the Nazi camps spread in the West among the allies. To quell the rumors, the Nazis chose Terezinstadt as a place to show to the international delegations of the Red Cross. According to Vera Schiff, the Nazis wanted to preserve their reputation and attempt to conceal their crimes. "Theresienstadt seemed destined to play a major role in the deception regarding the Nazis' treatment of the Jews. The camp could be adapted to conceal the actual conditions that prevailed there" (Schiff 2012, 11). The series showed the visit of the Red Cross from Sweden, who, among other things, visited the artists in Terezin. On that occasion, he was shown the pictures of the false state of the camp painted by the artists, and a German soldier, in order to support these scams says, "Who ever heard of a prison with an art studio?"

However, the Terezin shown to foreign delegations and the actual conditions of life were largely different. As the documentary and historical documents state: "The propaganda role of the camps was perfected for months, so for the purpose of international visits and documentary films the prisoners had to plow the fields, cultivate fruit trees, children were playing, theatrical performances were shown“ (Radulić 2009). Real life in Terezin was far different from this.

Although the series Holocaust shows a number of events and places in World War 2, the concept of Theresienstadt is one of the main ones depicted, as evidenced by the fact that the last scene of the series shows Theresienstadt itself. Namely, the only remaining alive protagonists in the series are Inga (Meryl Streep) and Rudi (Joseph Bottoms) who re-unite in liberated Theresienstadt. The final scene shows Rudi who plays football with the Greek children in Theresienstadt.

The reuniting of the main protagonists, and smiling and cheerful children at the end of the series are the features of a melodramatic approach to the topic. As Daković says: "Even a brief look at the texts confirms that these are generally well-tailored classic melodramas that follow the rules of the genre: a happy end with the spiritual reward, triumph of virtue and integrity, revelation of secrets from the past. Personal, emotional stories are taking place at the same time as public, historical turmoil happens, which are actually the main obstacle to the fulfillment of wishes in accordance with the imperative of making the story personal in order to have a hypertrophied emotional and ethical effect" (Daković 2014, 161). 


\section{CONCLUSION}

The uniqueness of Terezin compared to the other camps is reflected in the fact that it was a Nazi camp for propaganda. The Nazis presented it to the world as a "reputable ghetto" which accommodated elderly and prominent Jews from Germany and Austria. It is said that the first commander in Terezin told the first Jewish town administrator: "Your people have no idea of how well they will be here. We'll make a paradise ghetto from Theresienstadt" (Berkley 1993, 13).

As written by Radulić, although life in Terezin was bearable, compared to most of the other concentration camps, especially those in Poland, people were also dying in Theresienstadt every day - from malnutrition, disease, abuse and executions. "Viewed from the outside Theresienstadt functioned as a small town. It seemed able to take care of the citizens from birth to death through an orphanage, hospital, police, central kitchens, sports building, electricity and waterworks, employment office, bank, old people's home. From the inside you saw a strange entity which is best described as a concentration assembly and thoroughfare camp, a station on the way to extermination in Auschwitz" (Sode-Madsen 1993, 273-274).

Although the NBC network was criticized for commercializing a tragedy, and the series was accused of presenting a complex topic through a trivial family story similar to a soap opera, the creators of the series nevertheless said that this series was an important factor for raising awareness of the Holocaust, and also that this was the first opportunity for Americans to see a feature-length dramatization of the Holocaust, by seeing the victims and their personal stories through the protagonists. As said by Dakovic "The triviality of fictionalization and genre sharply criticized when television mini-series Holocaust and Schindler's List were first broadcast became a model of text survival topics" (Daković 2014, 150).

When the series was broadcast in West Germany in January 1979, the spectators' response was surprising. Results of surveys aimed at capturing public reactions before, immediately after, and a few months after the broadcast of the series, showed that this unique television show had a significant impact on how residents of West Germany understood the events from the recent history of their country.

The series Holocaust is undoubtedly an important part of television history, but also a significant memorabilia and a culture of remembrance. In fact, the very existence of these media texts "talks about the representation and narration about the Holocaust as a never ending process that passes through various cinematic genres and media forms, linking many representations into an unfinished and undeveloped hypertext - a narrative that is not an enclosed set of facts but an archive project of remembrance that is constantly developing" (Daković 2014, 165).

The concept of Theresienstadt in the series Holocaust corroborates the statement that this camp was used for the purpose of propaganda rearticulation of a crime against civilization and it reveals the hidden and repressed fear and horror underneath the smiling façade of Theresienstadt. The colorfulness of the exterior in the scenes which show Terezin, and on the other hand a horror interior, as well as everything that was happening behind the scenes expressed in the form of secret images of the artists, clearly emphasize the living conditions in Theresienstadt, as well as its role in Nazi propaganda. 


\section{REFERENCES}

Berkley, George. Hitler 's Gift: The Story of Theresienstadt. Boston: Branden Books, Boston, 1993.

Daković, Nevena. Studije filma: Ogledi o filmskim tekstovima sećanja. Beograd: Fakultet dramskih umetnosti, Institut za pozorište, film, radio i televiziju, 2014.

Margry, Karel. "Theresienstadt' (1944-1945): The Nazi Propaganda Film Depicting the Concentration Camp as Paradise." Historical Journal of Film, Radio and Television 12, 2 (1992): 145-162.

Margry, Karel. "The First Theresienstadt Film (1942)." Historical Journal of Film, Radio and Television 19, 3 (1999): 309-337.

Prager, Brad. "Interpreting the Visible Traces of Theresienstadt." Journal of Modern Jewish Studies 7:2 (2008): 175-194.

"Propaganda: Pogledajte kako su nacisti lažirali život u jevrejskom getu.” Buka, December, 05, 2013. Accessed April 09, 2016. http://www.6yka.com/novost/45288/propaganda-pogledajte-kako-su-nacisti-lazirali-zivotu-jevrejskom-getu-foto

Radulić, Hana. "Smrt u službi propagande." Zadarski list, September 05, 2009. Accessed April 09, 2016. http://www.zadarskilist.hr/clanci/05092009/smrt-u-sluzbi-propagande

Schiff, Vera. The Theresienstadt Deception, The Concentration Camp the Nazis Created to Deceive the World. Lewiston: The Edwin Mellen Press, 2012.

Sode-Madsen, Hans. "The Perfect Deception. The Danish Jews and Theresienstadt 1940-1945." Leo Baeck Institute Yearbook 38, 1 (1993): 263-290. Accessed April 10, 2016. doi:10.1093/leobaeck/38.1.263

Trzun, Zvonko. "U kinu sa nacistima.” POLEMOS: časopis za interdisciplinarna istraživanja rata i mira XII, 23 (2009): 131-135.

\section{PROPAGANDNA REARTIKULACIJA CIVILIZACIJSKOG ZLOČINA: KOCEPT TEREZINŠTATA U SERIJI HOLOKAUST}

Najozloglašeniji logori za istrebljenje ili logori smrti bili su Aušvic, Belzec, Treblinka i drugi. Osim logora smrti, nacisti su stvarali $i$ koncentracione radne logore u kojima su iskorišćavali radnu snagu. Po svojoj funkciji, jedan od jedinstvenih logora bio je Terezinštat, koji je u novembru 1941. godine postao nacistički koncentracioni logor za Jevreje. Terezin je, naime, reklamiran kao banja za bogate starije građane kojima su obećavani sigurnost i luksuz. Medijski tekstovi sa temom Holokausta postali su značajan segment kulture sećanja. Američka televizijska mini-serija Holokaust jedan je od medijskih narativa koji se bavi civilizacijskim zločinom i premijerno je emitovana 1978. godine. Koncept Terezinštata u seriji Holokaust potkrepljuje tvrdnju o iskorišćenju ovog logora u svrhu propagandne reartikulacije civilizacijskog zločina. Šarenilo spoljašnjosti predstavljeno u kadrovima kojima se prikazuje Terezin $i$ sa druge strane horor unutrašnjosti, svega onoga što se iza kulisa dešavalo, opredmećen u tajnim slikama umetnika, jasno ukazuju na uslove života koji su u Terezinštatu vladali, kao i na njegovu ulogu u nacističkoj propagandi.

Ključne reči: propaganda, Holokaust, Terezinštat, medijski tekstovi, kulura sećanja 